\title{
İş Stresi, İş Tatmini, Örgütsel Kıvanç ve İşten Ayrılma Niyeti Etkileşiminin İş Performansıyla İlintisi
}

\section{A Connection of the Interaction between Job Stress, Job Satisfaction, Organisational Pride and Intention to Leave to Job Performance}

\author{
Aslı ERCAN, Türkiye, ercan.ercanasli@gmail.com \\ Orcid No: 0000-0003-2479-0919 \\ İpek KAZANÇOĞLU, Ege Üniversitesi, Türkiye, ipek.savasci@ege.edu.tr \\ Orcid No: 0000-0001-8251-5451 \\ Berk KÜÇÜKALTAN, Trakya Üniversitesi / University of Bradford, Türkiye / United Kingdom, \\ berkkucukaltan@trakya.edu.tr \\ Orcid No: 0000-0002-2766-3248
}

\begin{abstract}
Öz: Satış odaklı işletmeler, rekabet üstünlüğ̈̈ sürdürebilmek ve pazar lideri olmak için satış hedeflerini gerçekleştirmek zorundadır. Bu hedeflere ulaşabilmek için işletmelerin, satış temsilcilerine ve onların yeteneklerine, kabiliyetlerine ihtiyaçları vardır. Ancak, satış mesleği, tabiatı itibariyle çalışanlarda işsten kaynaklı strese yol açmaktadır. Bunun yanı sıra, yönetici davranışı, maddi imkânların önemi, kariyer olanaklarının kısıtlı olması gibi unsurlar da iş tatmininin azalmasına sebep olmaktadır. Ayrıca, karşılanmayan beklentiler çalışanların verimini düşürmektedir. Dolayısıyla, tüm bu durumlar satış temsilcilerinin işten ayrılmalarına neden olabilmektedir. Buradan hareketle, mevcut çalışma, iş stresi, iş tatmini, örgütsel kivanç temalarının iş̦ten ayrılma niyeti ile etkileşimini ve iş performansıyla ilinti unsurların araştıılmasını amaçlamaktadır. Bu kapsamda, telekomünikasyon sektöründe görev yapan satış temsilcileriyle yüz yüze derinlemesine mülakatlar gerçekleştirilmişstir. Bulgular, QSR-Nvivo 11 Plus araştırma programı yoluyla incelenmiştir. Nitel içerik analizi sürecinde, oluşan temalar, alt temalar ve kodlar sonrasında haritalandırllmıştır. Sonuç olarak bulgularda, iş stresine yol açan en önemli kaynakların hedef baskısl, iş yükü, yönetici unsuru olduğu ortaya çıkmaktadır. Ayrıca, ücret-yan ödemeler-ödül ve yönetici davranışının, çalışanların iş tatminini etkilediği belirlenmiştir. Örgütsel kivanç temasının duygusal boyutunun, iş performansıyla ve işe aidiyet alt temast ile ilintili olduğu tespit edilmişstir. Bu sonuçlar kapsamında, iş stresi,işin maddi/manevi tatmini, iş performansi, ișyerine duyulan örgütsel kivanç ve işten ayrlma niyetinin,satış temsilcilerinde incelenmesi çalışmanın önemini ve değerini oluşturmaktadır. Netice itibariyle, çallş̧madan elde edilen bulgular akademik alanda olduğu kadar, işletmelerin başarısında etkili olan çalışan performasının artırlmasına yönelik insan kaynakları stratejileri geliştirmesi için de yol gösterici niteliktedir.
\end{abstract}

Anahtar Sözcükler: İ̧s Stresi, İş Performansı, İş Tatmini, İşten Ayrlma Niyeti, Örgütsel Kıvanç

Abstract: Sales-oriented businesses have to achieve their sales targets in order to maintain their competitive advantages and to become a market leader. For achieving these targets, businesses need sales representatives with their skills and capabilities. However, the sales profession inherently leads to job-related stress for employees. Moreover, factors such as executive behaviour, the importance of financial potentials and the limited career opportunities cause a decrease in job satisfaction. In addition to these, unmet expectations also reduce the productivity of employees. Accordingly, all these situations may lead sales representatives to leave their jobs. From this point forth, the present study aims at investigating both the interactions between intention to leave and job stress, job satisfaction, organisational pride themes and their connection to job performance-related factors. In this regard, in-depth interviews were conducted face-to-face with sales representatives working in the telecommunication industry. The findings were examined through the QSR-NVivo 11 Plus research program. The themes, sub-themes, and codes revealed from the qualitative content analysis process were then mapped. Consequently, in the findings, the most important sources that cause job stress are revealed as target pressure, work load, and executive factor. Furthermore, it is determined that wage-side payments-reward and executive behaviours influence the job satisfaction of employees. It is also found that the emotional dimension of the organisational pride theme is related to job performance and the sub-theme of belonging to work. Based on these findings, investigating job stress, material/moral job satisfaction, job performance, organisational pride, and intention to leave of sales representatives forms the importance and value of the study. As a result, the findings obtained from this study provide a guidance not only to the academic field, but also for the strategy development of human resources in practice in order to increase employee performance, which are effective in the success of businesses.

Keywords: Job Stress, Job Performance, Job Satisfaction, Intention-to-Leave, Organisational Pride

\section{Giriş}

Hizmet sektöründe çalışan satış temsilcileri, işletmelerde hizmet-ürün-müşteri bağlılığı aracıllğıyla rekabet ve kârlılı̆g destekleyen, en önemli stratejik güç unsuru olarak görülmektedir. Aş̧ırı iş yükü, baskı oluşturan hedefler, müşterilerden kaynaklı olumsuz davranışlar, satış temsilcilerinde iş rolleri bağlamında stres yaratmaktadır. İş stresinden kaynaklı performans düşüklüğü, iş tatmini azalışı gibi olumsuzluklar çalışanların işten ayrılma niyetlerinin oluşumuna sebep olabilmektedir. Dolayısıyla, bu çalışma, bir yandan satış temsilcilerinin yaşadığı iş stresi, iş tatmini, örgütsel kıvanç temalarının işten ayrılma niyeti ile etkileşimini incelerken, diğer yandan her bir temanın iş performansıyla ilgisini de araştırmaktadır. Literatürde, işten ayrılma niyeti ile ilintili olabilecek faktörlerden iş stresi, iş tatmini, örgütsel kıvanç ve iş performansını bir arada değerlendiren çalışmaların yetersizliği belirlenmiştir. Ayrıca yoğun iş stresi altında performans odaklı çalışan satış personeli örnekleminde bahsi geçen bu önemli unsurların araştırılması da bu çalışmanın özgünlüğünü ortaya çıkarmaktadır. Bu bağlamda, mevcut çalışma sayesinde, bahsi geçen faktörler ile işten ayrılma niyetinin 
Ercan, A., Kazançoğlu, İ., Küçükaltan, B. / Journal of Yasar University, 2019, 14 (Special Issue), 101-114

ilişkilendirilmesi ve bu ilişkilerin satış temsilcileri örnekleminde derinlemesine araştırılması ile alan yazına önemli katkılar sağlanabileceği düşünülmektedir.

\section{Literatür Araștırması}

\section{1. İş Stresi}

Literatürde iş stresinin tam olarak kabul görmüş bir tanımı mevcut olmasa da, günümüz çalışma şartlarında insan unsurunun sıklıkla karşılaştığ bu durum, araştırmalara dahil edilmesi gereken önemli bir unsurdur (Jaramillo vd., 2005). İş stresi, çalışanın, işin yapılabilmesi için ondan talep edilen özellikler ile bu talepleri gerçekleştirme yeteneği arasındaki uyumsuzluk algıladığında oluşmaktadır (Williams vd. 2001'den akt. Bhuiana, Menguc ve Borsboom, 2005). İşs stresi çalışanların verimliliklerine, performanslarına, işten tatmin düzeylerine ve işten ayrılma niyetlerine doğrudan etki edebilmektedir (Firth vd., 2004;Onay ve Kılc1, 2011). İş stresini yaratan koşullar incelendiğinde, rol belirsizliği, kurum içi çatışmalar, aşırı iş yükü öne çıkan unsurlar olabilmektedir (Armağan ve Kubak, 2013).

İş stresinin yoğun olarak yaşandığı meslek dallarından biri, belki de en sık karşılaşılanı satış temsilciliğidir. Satışa ilişkin meslekler, artan müşteri tatminini karşılamayı amaçlarken, yapısı gereği belirsiz ve çelişkili durumlar içerdiğinden dolayı stresli olarak kabul edilmekte ve bu çetin koşullarda, özellikle günümüzde artan rekabette, satış personelleri az kaynak kullanmak zorunda bırakılarak iş yükleri arttırılmaktadır (Bande vd., 2015). Bu hususta, Faiz (2019), satış personellerinin insan ilişkilerinde iletişim tekniklerini yoğun kullandıklarını ancak mesai sürelerinin dinamik olduğunu da belirtmiştir. $\mathrm{Bu}$ anlamda, her ne kadar satış personelinin davranışlarını ve performansını etkileyen önemli faktörlerden biri de duygu olmasına rağmen, işyerine dair duygular ve bilhassa bu duyguların satış personeli ile olan bağlantısı halen araştırmalarda eksik kalan bir çalışma alanı olarak karşımıza çıkmaktadır (Bande vd., 2015). Tüm bu kısıtlar ve zorlayıcı şartlar altında çalışan, müşteri temelli sorunlarla uğraşan satış personellerinin yaşadıkları stres de ön plana çıkmaktadır (Ercan ve Kazançoğlu, 2019). Sürekli satış baskısı altında satış personelinin hissettiği iş stresi, performansını (Banerjee ve Mehta, 2016; Olusegun vd., 2014), müşteri ilişkilerini ve işgücü devir hızını olumsuz etkilemektedir (Schwepker ve Ingram, 2016).

\section{2. İs Tatmini}

Eren (2010:202) iş tatminini, "işten elde edilen maddi çıkarlar ile işçinin beraberce çalışmaktan zevk aldığı iş arkadaşları ve eser meydana getirmenin sağladığı bir mutluluk" olarak tanımlamıştır. "İstenen bir şeyin gerçekleşmesini sağlama, gönül doygunluğuna erme anlamlarını" barındıran tatmin kelimesi, "İhtiyaçların tatmin edilmesi sonucu oluşan mutluluk durumu” olarak tanımlanmaktadır (Halsey, 1988'den akt. İşcan ve Sayın, 2010:198).

İş tatmini, çalışanların işleriyle ilgili tutum, tavır ve duyguları olarak da tanımlanabilir. Olumlu ve istenen davranışlar iş tatminini ortaya çıkartırken; olumsuz ve istenmeyen davranışlar çalışanın işe duyduğu memnuniyetsizliği göstermektedir (Armstrong ve Taylor, 2014). Çalışanlarda iş tatmini, iç ve dış olmak üzere iki boyutta açıklanmaktadır. İçsel doyum; "işin kendisi ve yapılış şekli, iş sorumluluğu, başarı, tanınma, kariyer olanakları, takdir edilme, terfi”" (Erdem ve Erkan, 2015:355) gibi işin kendisinden kaynaklanan unsurlar olarak tanımlanırken; "üst yönetimin politikası, denetim, üst-ast ilişkileri, çalışma koşulları ve ücret gibi” (Erdem ve Erkan, 2015:355), işin örgütteki çevresel unsurları dışsal doyum olarak tanımlanmaktadır.

İş tatmini, çalışma ortamında meydana gelen durumlara karşı gösterilen duygusal bir tepki olduğundan manevi olarak hissedilebilir ve gözlemlenemez, ölçülemez. İş tatmini, çalışan beklentisinin karşılanma düzeyi ile ilgili olmakla birlikte, çalışanlardaki iş tatmini düzeyi görecelidir. İş tatmini, işin farklı boyutlarına karşı farklı davranış ve tutumları belirttiği için işin boyutları arasında doyum farklılığı olabilmektedir. Sonuç olarak, çalışanların hissettiği iş tatmini, maddi ve manevi yönleri ile incelenebilmektedir (Üngören vd., 2010).

\section{3. Örgütsel Kıvanç}

Örgütsel kıvanç; "çalışanların işletmelerinin bir parçası olmaktan duydukları kıvanç, işletmenin ününden çalışana yansıyan haz” (Cialdini vd., 1976'dan akt. Çekmecelioğlu ve Dinçel, 2014:83) olarak tanımlanmaktadır. Ayrıca “çalışanların kuruma olumlu duygular hissetmesi” (Mischkind,1998'den akt. Durrah vd., 2019:4) ve performans ile ilişkili bir duygu (Gouthier ve Rhein,2011) olarak da belirtilmektedir. Örgütsel kıvanç, çalışan tarafından yapılan statü değerlendirmelerine bağlı olarak örgüte duyulan hayranlık, önem ve değer olarak en yoğun duygulardan birini oluşmaktadır (Arnold vd., 2009).

Örgütsel kıvanç, iş tatmini ile de ilintilidir (Gunter ve Furnham, 1996). Bu yönde yapılan çalışmalarda örgütsel kıvancın iş stresine karşı direnci arttırdığ 1 ve işten ayrılma niyetini azalttığ 1 vurgusu yapılmıştır (Gouthier ve Rhein,2011; Kraemer ve Gouthier, 2014). Ayrıca, örgütsel kıvanç, sadece çalışanların olumsuz duygularını azaltmakla kalmayıp, aynı zamanda işyerinde görevine devam etme kararını olumlu yönde etkilemekte ve işgören bağlılı̆̆ı, özerklik, takım desteği ve yönetici-ast arasındaki ilişkileri de teşvik etmektedir (Kraemer ve Gouthier, 2014; Durrah vd., 2019).

Örgütsel kıvancın duygusal ve davranışsal kıvanç olarak iki boyutu bulunmaktadır (Gouthier ve Rhein,2011). Duygusal kıvanç, kısa ömürlü fakat yoğun zihinsel deneyim gerektirmektedir (Basch ve Fisher, 2000). Çalışanlar, meslektaşlarının, çalışma grubunun veya genel olarak şirketin başarılarıyla gurur duyarak, örgütsel kıvanç duygularını arttırabilmektedirler. Kıvanç duyguları, iş tatmini gibi iş tutumlarıyla ilintili olabilmektedir. Davranışsal kıvanç ise, 
çevrenin olumlu ya da olumsuz izlenimine, çalışanın deneyimine dayanan, öğrenilebilir, zamanla gelişebilen, bireyin çalıştığı örgütüne karşı hissettiği yüksek beğenme derecesine sahip, uzun vadeli bir kavramdır (Fairfield ve Wagner, 2004; Gouthier ve Rhein, 2011). Davranışsal örgütsel kıvanç, çalışanın bağlılığına doğrudan ve çalışan yaratıcılığına dolaylı olarak olumlu yönde bir etkide bulunmaktadır. Örgütsel kıvanç, hizmet sektöründe örgütsel rekabetçiliğe de katkıda bulunmaktadır (Gouthier ve Rhein, 2011).

Türkçe literatürde bu konu üzerine sınırlı çalışmanın yapılmış olması, bu kavramın mevcut çalışmadaki önemini ve katkısını da arttırmaktadır. Çekmecelioğlu ve Dinçel'in (2014) örgütsel kıvanç, iş tatmini ve örgütsel bağlılık arasındaki ilişkiyi araştıran çalışmasında; çalışanların çalıştıkları kuruma karşı hayranlık ve iyi duygular hissetmelerinin, kurumun adını gururla söylemelerinin, onların hem iş ve ücret tatminini, hem de örgütsel bağlılıklarını arttırdığına dikkat çekmiştir. Yabancı literatürde ise, Helm (2011) örgütsel kıvancın iş tatmini ve örgütsel bağlılığı arttırdığını saptamıştır. Örgütsel kıvanç, satış temsilcisinin performansına ilişkin motivasyonunu arttırmaktadır (Verbeke vd., 2004). Bu bağlamda, çalışan tarafından deneyimlenen kıvanç duygusu etkili bir motivasyon aracına dönüşmektedir. Kurumsal ve işveren markası olarak, bilinen işletmede çalışan satış temsilcilerinin çalıştığı firmaya hissettiği kıvanç duygusunun, algılanan olumsuz duyguların oluşmasını azaltabileceği ve bu vesileyle işten ayrılma niyetini etkileyebileceği kanaati oluşmuştur. Satış yeteneği güçlü çalışan, işletmenin performansının, verimliliğinin ve başarısının belirlenmesinde önemli rol oynamaktadır. $\mathrm{Bu}$ nedenle, çalışanların işten ayrılma niyetlerinin anlaşılması ve buna etki edebilecek unsurların anlaşılması önemlidir.

\section{4. İșten Ayrılma Niyeti}

İşten ayrılma niyeti, çalışanın mevcut işinden ayrılma düşüncesine sahip olarak geçirdiği süre şeklinde tanımlanmaktadır (Fong ve Mahfar, 2013). Bu düşünceye sahip çalışanların mevcut işlerindeki koşullar beklentilerini karşılamadığ takdirde, işlerinden ayrılma eğilimi göstereceklerdir (Polat ve Meydan, 2010). İş stresi, iş tatmini ve işten ayrılma niyeti üzerine yapılan araştırmalar literatürde farklı bakış açılarından incelenmiş ve farklı örneklem grupları çalışmalara dâhil edilmiştir. Örneğin, Turunç ve Çelik (2010) örgütlerin verimliliklerini arttırmak amacıyla insan faktörüne odaklanmaları gerektiği gerçeğinden hareket ederek, çalışma yaşam kalitesinin arttırılmasını öncelik olarak belirlemiş ve bu kavramın ilişki içinde olabileceği prosedür adaleti, iş tatmini, iş stresi ve işten ayrılma niyeti üzerine ampirik araştırmada bulunmuşlardır. Performans odaklı bir çalışmada ise, Tekingündüz vd. (2015) çalışan performansı, iş stresi, iş tatmini ve işten ayrılma niyeti arasındaki ilişkiyi analiz etmiştir. Çalışma bir devlet hastanesi çalışanlarına uygulanmış ve analizler, çalışan performansının iş stresine kıyasla iş tatmininden daha çok etkilendiği sonucunu göstererek iş tatmin düzeyinin artmasıyla performans artışı gerçekleşebileceğini işaret etmiştir. Ancak tüm bu çalışmalar, her ne kadar araştırma konumuz ile ilişkili gözükse de, araştırmaların örneklemi devlet üniversitelerinde çalışan öğretim üyeleri ile ya da banka veya hastane çalışanları ile sınırlı kalmıştır ve bu anlamda farklılaşmaktadır.

$\mathrm{Bu}$ bağlamda, satış personeli üzerine yapılan araştırmaların nispeten az olduğu da yapılan literatür araştırmasında ortaya çıkmıştır. Bu alanda yapılan az sayıdaki araştırmalardan, Faiz'in (2019) yaptı̆̆ı araştırmada, aşırı iş yükü ve tükenmişlik sendromunun işten ayrılma niyeti üzerine olan etkisi Düzce ilindeki farklı perakende sektörü işletmelerinde çalışan 300 satış personeli örnekleminde incelenmiştir. Çalışmanın analizlerinden, tükenmişlik sendromunun göstergelerinden olan duygusal tükenme ve duyarsızlaşmanın arttıkça, işten ayrılma niyetinin artabileceği sonucu çıkarılırken, kişisel başarıda azalma hissi göstergesinin işten ayrılma niyeti üzerinde anlamlı bir etkisinin olamayacağı saptanmıştır. İş yükü açısından ise çalışmada, fazla iş yükünün işten ayrılma niyetine etki edebileceği belirtilmiştir.

İncelenen kavramlar neticesinde, yerli yazının yanı sıra, literatürde satış personelini konu alan yabancı kaynaklar da eleştirel bakış açısı ile incelenmiş ve bu anlamda, biraz daha farklı boyutların tartışıldığı gözlemlenmiştir. Bu kapsamda, Sager'in (1994) yaptığı çalışmada iş stresi odak noktasına alınarak irdelenmiş ve iş stresi, satış yöneticisinin davranışı, rol belirsizliği, rol çatışması, iş tatmini, örgütsel bağlılık ve işten ayrılma niyeti arasındaki ilişkiler bir işletmenin satış personeli örnekleminde değerlendirilmiştir. Araştırmanın sonucunda, yöneticinin düşüncesinin iş yerindeki rol çatışmasını azaltarak iş stresinde etkili olabileceği, iş tatmininin iş stresini azalttığı, iş stresinin örgütsel bağlılık aracılığıyla dolaylı yoldan işten ayrılma niyetini etkilediği elde edilmiştir. Bu durum, hem örgütsel bağlılığın, hem de iş tatmininin direkt olarak işten ayrılmayı etkileyebileceği kanaatini oluşturmuştur. Jaramillo vd. (2005) kâr amacı gütmeyen örgütler kapsamında yürüttüğü çalışmada, 150 polis memurunun iş stresi ile örgütsel bağlılık, ayrılma niyeti ve iş tatmini ilişkilerini analiz etmişlerdir. Çalışmanın sonucunda, işten ayrılma niyeti ile örgütsel bağlılık arasındaki anlamlı ilişkisinin yanı sıra, örgütsel bağlılık üzerinde yönetici desteği, grup uyumu ve iş tatmininin de etkili olduğu tartışılmıştır. Bande vd.'nin (2015) duygusal zekâ ve duygusal tükenmişliğe olan direnç odaklı araştırmasında, duygusal tükenmişlik ve işten ayrılma niyeti arası ilişkide duygusal yeteneklerin gelişmesinin teşvik edilmesinin iş stresini azaltarak işten ayrılma niyetinin de azalacağı vurgusu yapılmıştır. Bu alanda yapılan çalışmalar değerlendirildiğinde, satış personelinde ve/veya temsilcilerinde anket çalışması yapıldığı, ancak konunun derinlemesine araştırılmasına imkân tanıyan nitel çalışmaların eksik veya yetersiz olduğu tespit edilmiştir.

\section{5. İş Performanst}

İş performansı, bir çalışanın iş tanımında belirtilen işleri yerine getirme eylemlerinin, işveren tarafından değerlendirilmesini kapsamaktadır (Janssen ve Van Yperen, 2004; Yan vd., 2019). Deneyimi daha az olan satış personeli rol belirsizliği ve rol çatışması yaşaması durumunda performansı azalmaktadır. Yüksek iş tatmini özellikle deneyimli satış personelinin performansını arttırmaktadır (Yılmaz, 2002; Singh ve Das, 2013). Aksi halde, Jaramillo vd.'nin (2005) değindiği gibi, çalışanlardaki yüksek iş stresi, işten ayrılma niyetine ve düşük iş performansına neden olmaktadır. Diğer 
yandan, iş tatmini işten ayrılma niyeti ile olumsuz ilişkilendirilmektedir. Tüm bunlardan hareketle, satış personelinin iş stresi azaltıldığında hem performansı yükselecek, hem de işten ayrılma niyeti azaltılmış olacaktır (Jaramillo vd., 2005).

\section{Yöntem}

Araştırma yöntemi, literatür dahilinde belirlenen temalar çerçevesinde oluşturulan nitel bir çalışmadır. Çalışmada, verilerin toplanması ve temaların oluşturulabilmesi için derinlemesine görüşme yöntemi kullanılmıştır. Çalışmanın ana kütlesi telekomünikasyon sektöründe çalışan satış personelinden oluşmaktadır. Örneklem ise, telekomünikasyon sektöründe müşteri ile birebir çalışan beş satış personelini kapsamaktadır. Veri toplama sürecinde katılımcılardan alınan izne dayalı olarak ses kayıt cihazı kullanılmış ve görüşmeler kaydedilmiştir. Görüşmelerde katılımcılara toplamda 37 adet soru yöneltilmiş ve beş katılımcı için görüşme süresi toplam 140 dakika olarak ölçülmüştür. Araştırma verilerinin analizinde ise içerik analizi kullanılmıştır. Görüşme soruları; iş stresi, iş tatmini, işten ayrılma niyeti ve örgütsel kıvanç ile iş performansına yöneliktir. Görüşme soruları hazırlanırken işten ayrılma niyeti ile ilgili Pettijohn vd.'nin (2007); iş stresi ile ilgili Parker ve DeCotiis'in (1983); örgütsel kıvanç ile ilgili Gouthier ve Rhein'ın (2011); iş tatmini ile ilgili Yapraklı ve Yılmaz'ın (2007) çalışmalarından yararlanılmıştır. İş performansı ile ilgili ise, diğer kavramlarla olan genel ilişkisi bu çalışmada araştırılmıştır ve literatürdeki iş performansına yönelik çalışmalar bu hususta kılavuz niteliği taşımıştır. İş tatmini ile iş stresi ve işten ayrılma niyeti ilişkilerine yönelik bulgular, yüz yüze görüşme sonucunda tematik ifadeler ile desteklenmiştir.

\subsection{Araştırma Soruları}

Çalışmanın temelini oluşturan sorular aşağıdaki şekildedir:

- Satış temsilcilerinde, iş stresi, örgütsel kıvanç, iş tatmini ve işten ayrılma niyeti temaları hangi alt temalardan oluşmaktadır?

- Satış temsilcisinin hissettiği iş stresi, iş tatmini ve örgütsel kıvancın, işten ayrılma niyeti ile ilintisi nedir?

- İş stresi, iş tatmini, örgütsel kıvanç ve işten ayrılma niyetinin iş performansıyla ilintisi ne şekilde gerçekleşmektedir?

\subsection{Araştırmanın Geçerliliği ve Güvenilirliği}

Araştırma, Lincoln ve Guba'nın (1985, akt. Güler vd., 2015) nitel araştırmalarda geçerliliğin ve güvenilirliğin sağlanmasına yönelik geliştirdiği, "inandırıcılık", "transfer edilebilirlik", "değişmezlik", "teyid edilebilirlik" temel unsurlarına göre düzenlenmiştir. İnandırıcılık aşamasında elde edilen bilgilerin "doğruluğu ve inandırıcılığını” (Güler, vd. 2015:376) sağlamak amacıyla araştırmacı çeşitlemesinden yararlanılmıştır. Veriler, iki araştırmacı tarafından aynı zamanda ortak kodlama yapılarak düzenlenmiştir. Çalışmanın birden fazla teoriye, teorilerle ilgili görüşme sorularına ve araştırma sorusuna sahip olması da elde edilen verilerin doğruluğunu sağlamaktadır. Transfer edilebilirlik (genelleme) aşamasında ise, katılımcı bilgileri (demografik özelliklerin), temalar, alt temalar, kodlar tablo halinde düzenlenmiştir. Bu aşamadaki araştırma düzeni, bir başka sektörde veya farklı meslek gruplarında yapılacak araştırmalarda da kullanılabilecektir. Değişmezlik aşamasında ise, elde edilen bilgiler, ayrıntılı bir şekilde kodlanmış, temalara ayrılmış ve haritalandırılmıştır. Elde edilen temalar, farklı veya aynı sektördeki diğer örneklemlerde incelendiğinde benzer sonuçlar görülebilir (Güler, vd. 2015). Teyid edilebilirlik aşamasında, temalara yönelik ifadeler yanlılık sergilenmeden metin haline getirilmiş, katılımcı ifadeleri dışında, ifadelere herhangi bir ekleme yapılmamıştır.

\subsection{Bulgular}

Araştırma bulguları, telekomünikasyon sektöründe mağaza içi çalışan beş satış temsilcisi ile derinlemesine görüşmeler sonucunda elde edilmiştir. Tablo 1'de katılımcıların demografik özellikleri belirtilmiştir. Katılımcı ifadeleri, Nvivo 11 programına yüklenerek, tema ve alt temalara göre kodlanmıştır. Temalar, görüşme sorularının düzenlenmesinde yararlanılan ölçeklerin boyutlarından yararlanılarak düzenlenmiştir. Her bir temada yer alan alt temaların sıralaması o alt temada toplanan ifadelerin sayısına göre düzenlenmiştir.

Tablo 1. Demografik Özellikler

\begin{tabular}{|c|c|c|c|c|c|c|}
\hline Katılımc1 & Cinsiyet & Eğitim & Aylık Gelir (TL) & $\begin{array}{c}\text { Medeni } \\
\text { Durum }\end{array}$ & Yaş & $\begin{array}{c}\text { Aynı pozisyonda } \\
\text { çalışma y1lı }\end{array}$ \\
\hline K1 & Erkek & $\begin{array}{c}\text { Yüksek } \\
\text { Lisans }\end{array}$ & $4000-5000$ & Bekâr & 28 & 5 y1l \\
\hline K2 & Erkek & Lisans & $4000-5000$ & Evli & 28 & 6 y1l \\
\hline K3 & Kadın & $\begin{array}{c}\text { Özel } \\
\text { Lise }\end{array}$ & $3000-4000$ & Bekâr & 28 & 9 y1l \\
\hline K4 & Erkek & $\begin{array}{c}\text { Ön } \\
\text { Lisans }\end{array}$ & $3000-4000$ & Evli & 35 & 11 y1l \\
\hline K5 & Erkek & Lise & $4000-5000$ & Bekâr & 23 & 3,5 y1l \\
\hline
\end{tabular}




\subsection{1. İș Stresi}

İş stresi temasındaki ifadelerden, Tablo 2'de belirtildiği üzere hedef baskısı-prim, işyükü-çalışma süreleri, yönetici kaynaklı stres, müşteri kaynaklı stres ve özel hayat, tükenmişlik alt temaları saptanmıştır. Hedef baskısı-prim, işyüküçalışma süreleri ve yönetici kaynaklı stres alt boyutlarda ilk üç sırada yer almaktadır. Satış temsilcilerinin iş stresiyle ilgili bu üç alt boyut, çalışan stresinin artışında önemli bir rol oynamaktadır. Tükenmişlik alt teması ise, işten kaynaklı olması dolayısıyla hedef baskısı-prim ve işyükü-çalışma süreleri alt temaları ile ilintilidir. İş stresinin iş performansıyla ilgili ifadeleri iş performansı temasında yer almaktadır.

Tablo 2. İş Stresine İlişkin Tema, Alt Temalar ve İfadeler

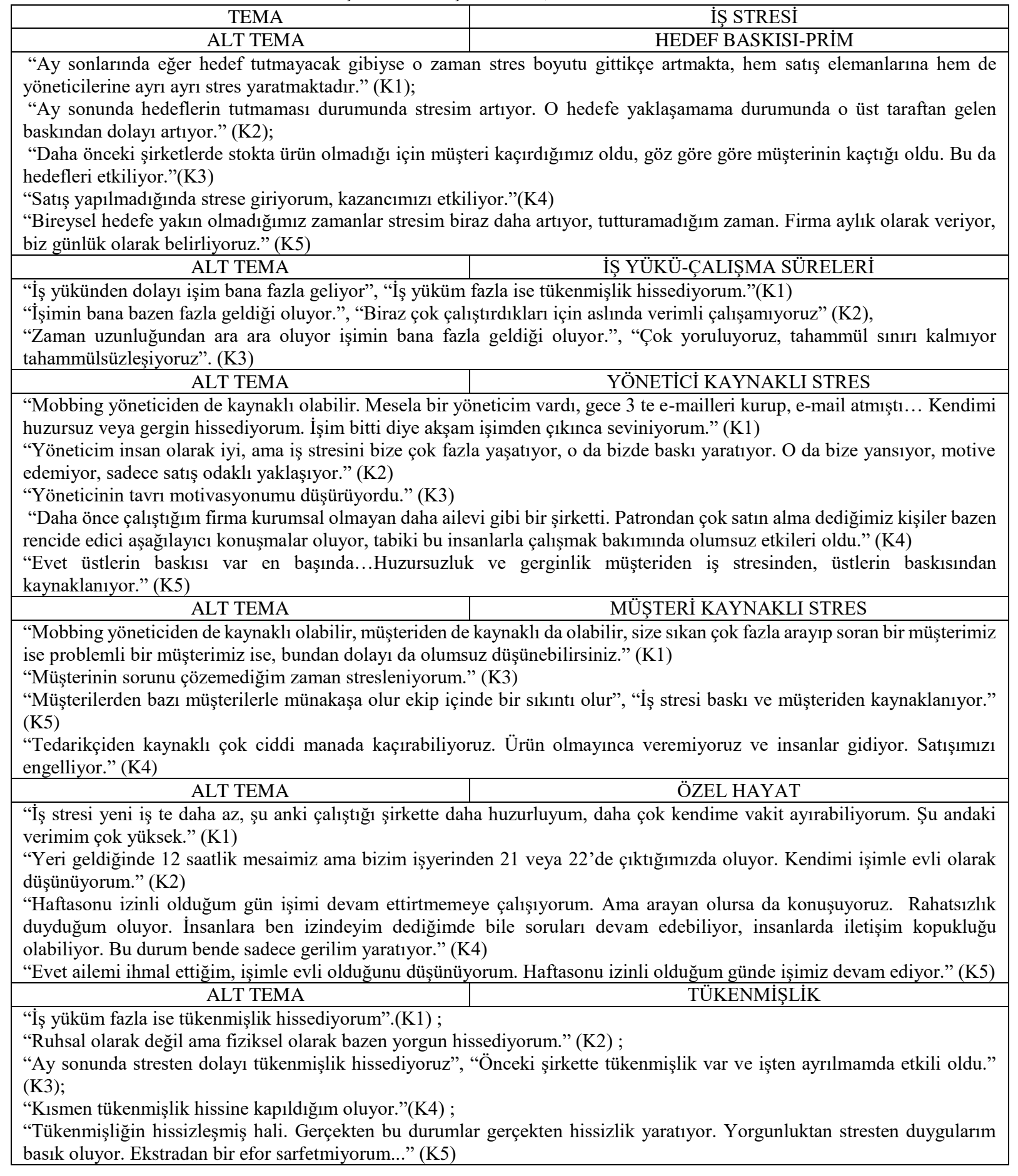




\subsection{2. İș Tatmini}

Araştırmanın bulgularına göre, iş tatmininin alt temaları; ücret-yan ödemeler-ödül, yönetici davranışı, çalışma arkadaşları, terfi (kariyer), işin kendisi olarak çıkmaktadır. Yapraklı ve Yılmaz’ın (2007) çalışmasında kullanılan ölçeğin alt boyutlarının beşi ile aynı olması pazarlama-satış sektöründe çalışanların iş tatmini boyutlarının değişmediğini göstermektedir. İş tatminine dair ifadeler incelendiğinde ise, ücret-yan ödemeler-ödül alt temasının, diğer iş tatmini alt temaları arasında ilk sırada yer aldığı ve bu açıdan önemli olduğu, devamında yönetici davranışının iş tatmini ile yüksek ilintili olduğu belirlenmiştir. En son olarak, iş tatmini teması sırasıyla çalışma arkadaşları, terfi (kariyer) ve işin kendisini sevme alt teması ile devam etmektedir.

Tablo 3. İş Tatminine İlişkin Tema, Alt Temalar ve İfadeler

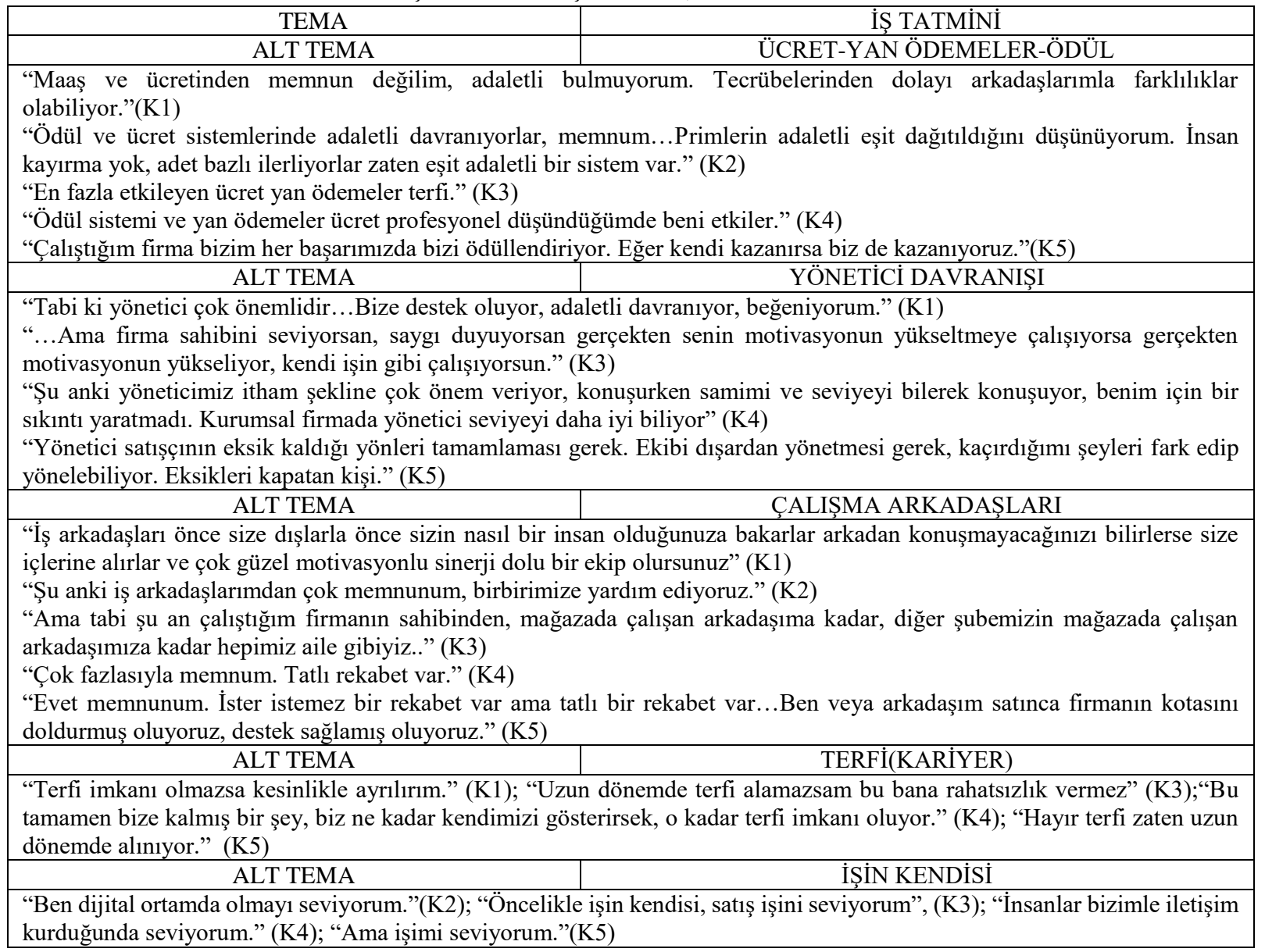

\subsection{3. Örgütsel Kıvanç}

Örgütsel kıvanç teması, görüşme sorularında duygusal kıvanç ve davranışsal kıvanç şeklinde iki alt tema olarak ele alınmıştır. Tablo 4'de belirtildiği üzere, duygusal kıvanç alt temasında, firmanın ve satış ekibinin üyesi olmak (özdeşleşme) ve başarı duygusu birer kod olarak ortaya çıkmaktadır. Başarı duygusu kodu, iş performansı ile karşılıklı ilintilidir. İfadelerden, satış temsilcisinin başarı duygusunda artış yaşandıkça, iş performansının da olumlu yönde etkilendiği belirlenmiştir. Davranışsal kıvanç alt temasında ise, tek kod olarak, firma isminin tanınırlığı (işveren markası) belirlenmiştir. Örgütsel kıvanç teması incelendiğinde, duygusal kıvancın ön plana çıktığı, davranışsal kıvanç alt temasına ait sorulardaki cevapların bir kısmının duygusal boyut temelli olduğu, firmanın ve satış ekibinin üyesi olmak ile başarı duygusu kodunu desteklediği belirlenmiştir.

Tablo 4. Örgütsel Kıvanca İlişkin Tema, Alt Temalar ve İfadeler

\begin{tabular}{|c|c|}
\hline TEMA & ÖRGÜTSEL KIVANÇ \\
\hline ALT TEMA & DUYGUSAL KIVANÇ BOYUT \\
\hline KOD & $\begin{array}{c}\text { FIRMANIN VE SATIŞ EKİBİNIN ÜYESİ OLMAK } \\
\text { (ÖZDEŞLEŞME) }\end{array}$ \\
\hline $\begin{array}{l}\text { "..sağlanan birkaç ayrıcalık, bunlar bende aidiyet hissi yaratmasını sağlıyor." (K2) } \\
\text { "Direkt duygusal olarak ağlama noktasına gelebiliyorum.", "Kendi firmam gibi çalışıyorum, çok gurur duyuyorum.", "Kendi } \\
\text { iş yerim olarak görüp, özenle çalışmamı sağliyor.","Yaşadığımız her problemi ben şirketim adına çözmeye çalışıorum, stres }\end{array}$ \\
\hline
\end{tabular}


Ercan, A., Kazançoğlu, İ., Küçükaltan, B. / Journal of Yasar University, 2019, 14 (Special Issue), 101-114

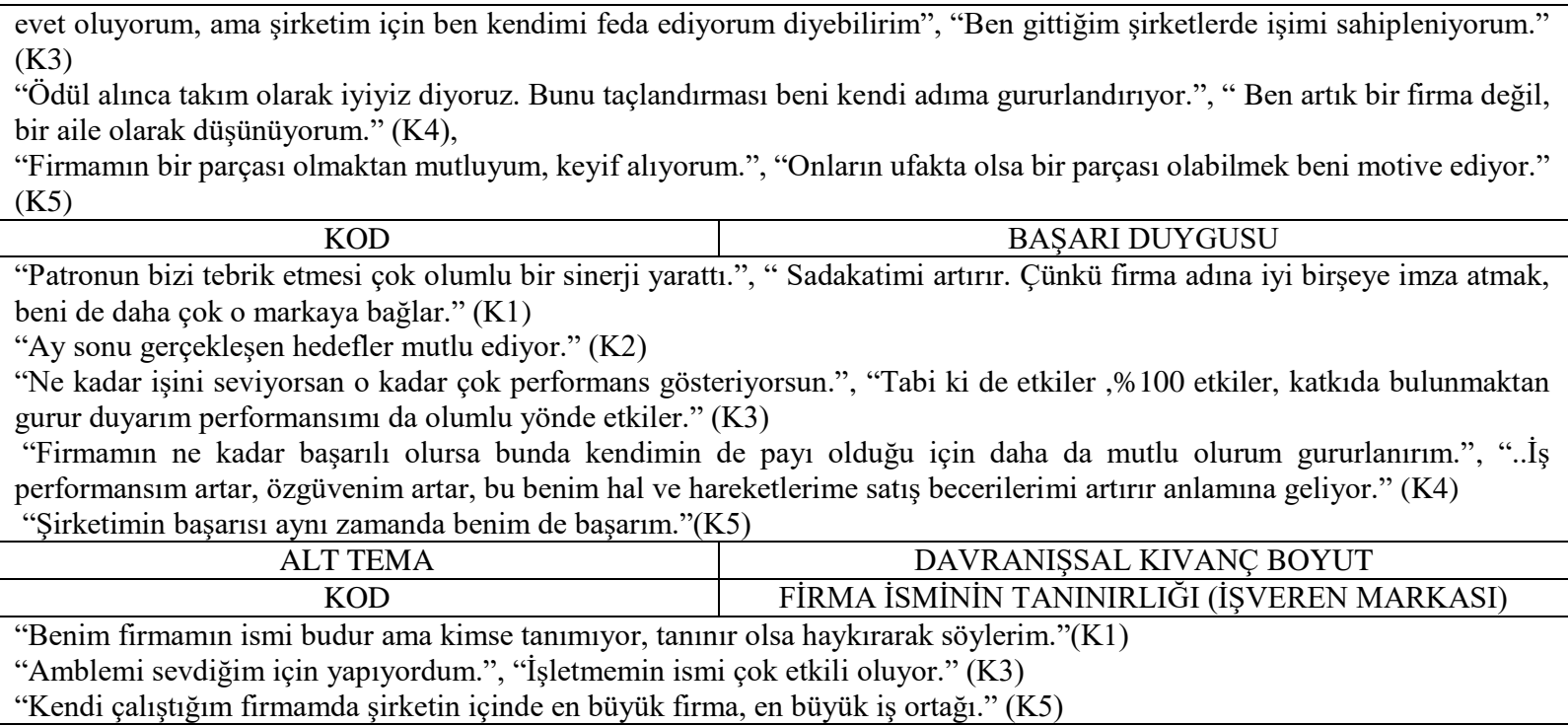

\subsection{4. İşten Ayrılma Niyeti}

Tablo 5'de görüldüğü üzere, işten ayrılma niyeti teması, yönetici davranışı, ücret-terfi, işe aidiyetin önemi, adaletsizlik, işyükü, çalışma ortamı ve özel hayat olarak altı alt tema şeklinde ifade sonuçlarında ortaya çıkmıştır. İşten ayrılma niyetinin altı alt temadan oluşması satış temsilcilerinin işten ayrılma davranışının çok boyutlu unsurlardan oluştuğunun bir göstergesidir.

Tablo 5. İşten Ayrılma Niyetine İlişskin Tema, Alt Temalar ve İfadeler

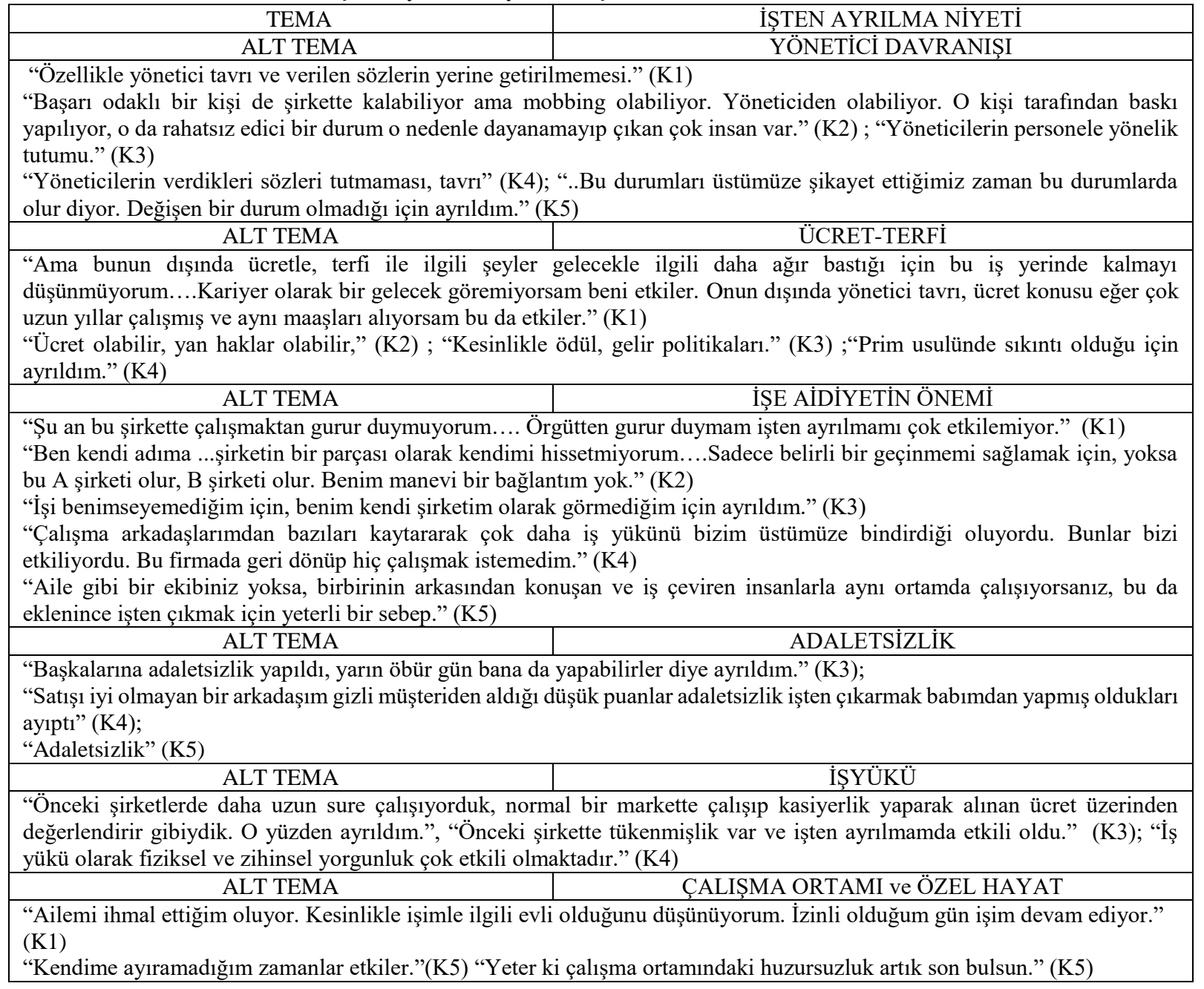




\subsection{5. İş Performansı}

Satış temsilcilerinin çalışma amacı satış olduğundan ve satışlardaki artışın örgüt başarısı ve performansı ile, dolayısıyla da iş performansı ve başarısı ile de bağlantısı olduğundan (Küçükaltan, 2018), satış-iş performansı bu örneklem grubu için hayati öneme sahiptir. Mevcut çalışmada, iş stresi, iş tatmini ve örgütsel kıvancın işten ayrılma niyetiyle etkileşimi araştırılırken, tüm bu temaların satış temsilcilerinin iş performansıyla ne şekilde ilintili olduğu da ayrıca incelenmiştir. Tablo 6'da iş performansıyla ilgili yönetici davranışı, çalışma ortamı, maddi ödüllendirme, ücret sistemi, profesyonellik, işe bağlılık gibi çeşitli unsurlar yer almaktadır. Tablo-7' de ise iş performansını etkileyen, olumlu-olumsuz iş stresi, işten ayrılma niyeti ve başarı duygusu temalarının ifadeler incelendiğinde, iş performansını iş stresi ve işten ayrılma niyetinin etkilediği belirlenmiştir. İş stresi temasıyla ilgili olarak katılımcılar, genelde performans düşüklüğü yaşadıklarını belirtmişlerdir. İki katılımcı iş stresinin olumlu yönünü bir sonraki satış davranışına yansıttıklarını ayrıca işleriyle ilgili gelişme sağladıklarını belirtmişlerdir. Gerçekleştirilen her satış, bir hedef tamamlama olduğundan ve akabinde ödülü getirdiğinden stresin olumlu yönünü oluşturmaktadır. Katılımcıların, işten ayrılma niyetleri oluştuğunda iş performanslarında da bir düşüş olabileceğini belirtmeleri bu iki temayı ilintili hale getirmiştir. Ayrıca örgütsel kıvancın duygusal kıvanç boyutunda yer alan başarı duygusunun ise, iş performansıyla olumlu yönde ilintili olduğu saptanmıştır.

Tablo 6. İş Performansına İlişkin İfadeler

\begin{tabular}{l|l} 
TEMA & IŞS PERFORMANSI
\end{tabular}

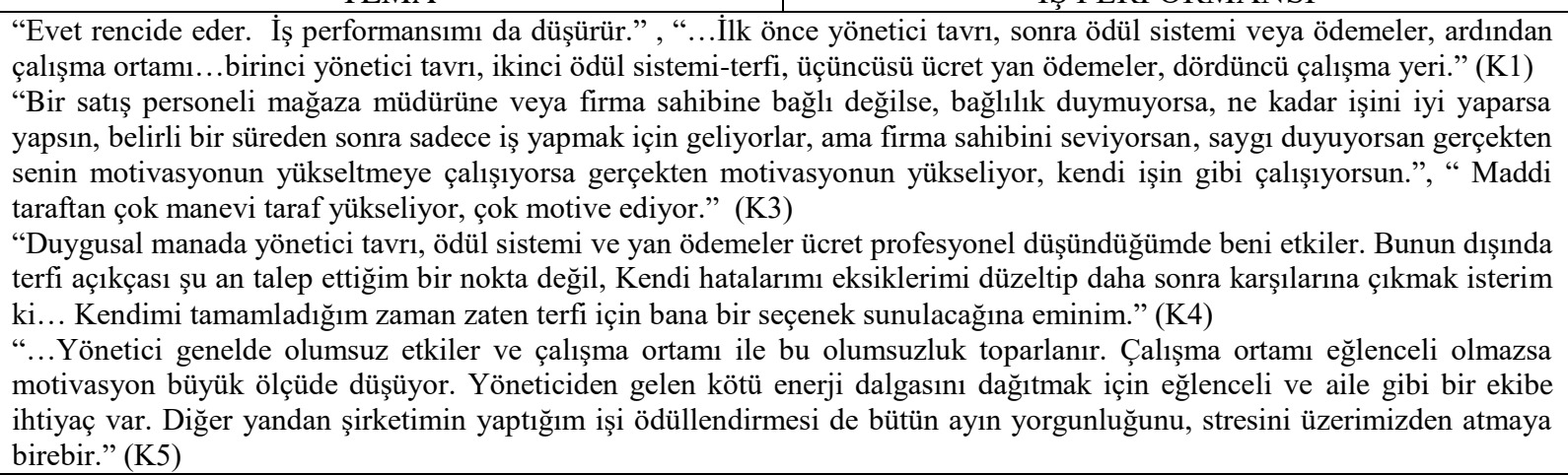

Tablo 7. İş Performansını Etkileyen Temalar ve İfadeler

TEMA $\quad$ OLUMLU-OLUMSUZ İŞ STRESİ

"Dışarıda sahada iş stresi benim performansımı artırıyor. ama içeride kendimi güvende hissedebileceğim yerde iş stresi yaşarsam direk motivasyonum düşer.", “Çok fazla iş yükü verilirse etkiler.”, “..İş stresi yeni işte daha az, şu anki çalıştığı şirkette daha huzurluyum, daha çok kendime vakit ayırabiliyorum. Şu andaki verimim çok yüksek..” (K1)

"Olumlu yanı, deneyim oluyor bize, bir sonraki sorunu nasıl karşılayacağımız çözeceğimiz konusunda yardımcı oluyor." (K3)

"Günlük hedeflerimizi gerçekleştirdiysek üstünü yapmak açısından bizi teşvik ediyor. daha çok yapıyım diye” (K4)

"Satış yaptıkça gelen motive hissi performansı olumlu etkiliyor ama eğer satış olmazsa ne kadar yoğunluk olursa olsun moral olmadığı için satış olmuyor." "Yönetici genelde olumsuz etkiler ve çalışma ortamı ile bu olumsuzluk toparlanır." (K5)

\begin{tabular}{l|l} 
TEMA & IŞTEN AYRILMA NIYYTI
\end{tabular}

"O zaman direk modum düşer. Direk çekerim elimi, yani olumsuz yansır. Sadece yapmam gerekeni yaparım. Yine üzerime düşeni yaparım ama yapmam gerekeni yaparım.”(K3);

"Bana verilen bir söz varsa ve o söz tutulmadıysa bu iş yerinden biraz daha devam etmem gerekiyorsa açıkçası performansım benim için çok önemli olmaz, performans göstermeye çalışmam." (K4);

"Eğer işten çıkmaya karar verirsem iş umurumda olmuyor." (K5)

\begin{tabular}{l|l} 
TEMA & BAŞARI DUYGUSU \\
\hline
\end{tabular}

"Patronun bizi tebrik etmesi çok olumlu bir sinerji yarattı.", " Sadakatimi artırır. Çünkü firma adına iyi bir şeye imza atmak, beni de daha çok o markaya bağlar." (K1)

"Ay sonu gerçekleşen hedefler mutlu ediyor." (K2)

"Ne kadar işini seviyorsan o kadar çok performans gösteriyorsun.", "Tabi ki de etkiler ,\%100 etkiler, katkıda bulunmaktan gurur duyarım performansımı da olumlu yönde etkiler." (K3)

"Firmamın ne kadar başarılı olursa bunda kendimin de payı olduğu için daha da mutlu olurum gururlanırım. "Işs performansım artar, özgüvenim artar, bu benim hal ve hareketlerime satı̧̧ becerilerimi artırır anlamına geliyor." (K4)

"Şirketimin başarısı aynı zamanda benim de başarım."(K5)

Görüşmelerden elde edilen ifadeler sonucu ortaya çıkan tüm tema, alt tema, kodlar ve aralarındaki ilintiler Nvivo 11 Plus programına girilmiştir. Programa girilen veriler sonucunda da, Şekil 1'de gösterilen haritalandırma görüntüsüne ulaşılmış ve tüm ilişkiler resmedilmiştir. 
Ercan, A., Kazançoğlu, İ., Küçükaltan, B. / Journal of Yasar University, 2019, 14 (Special Issue), 101-114

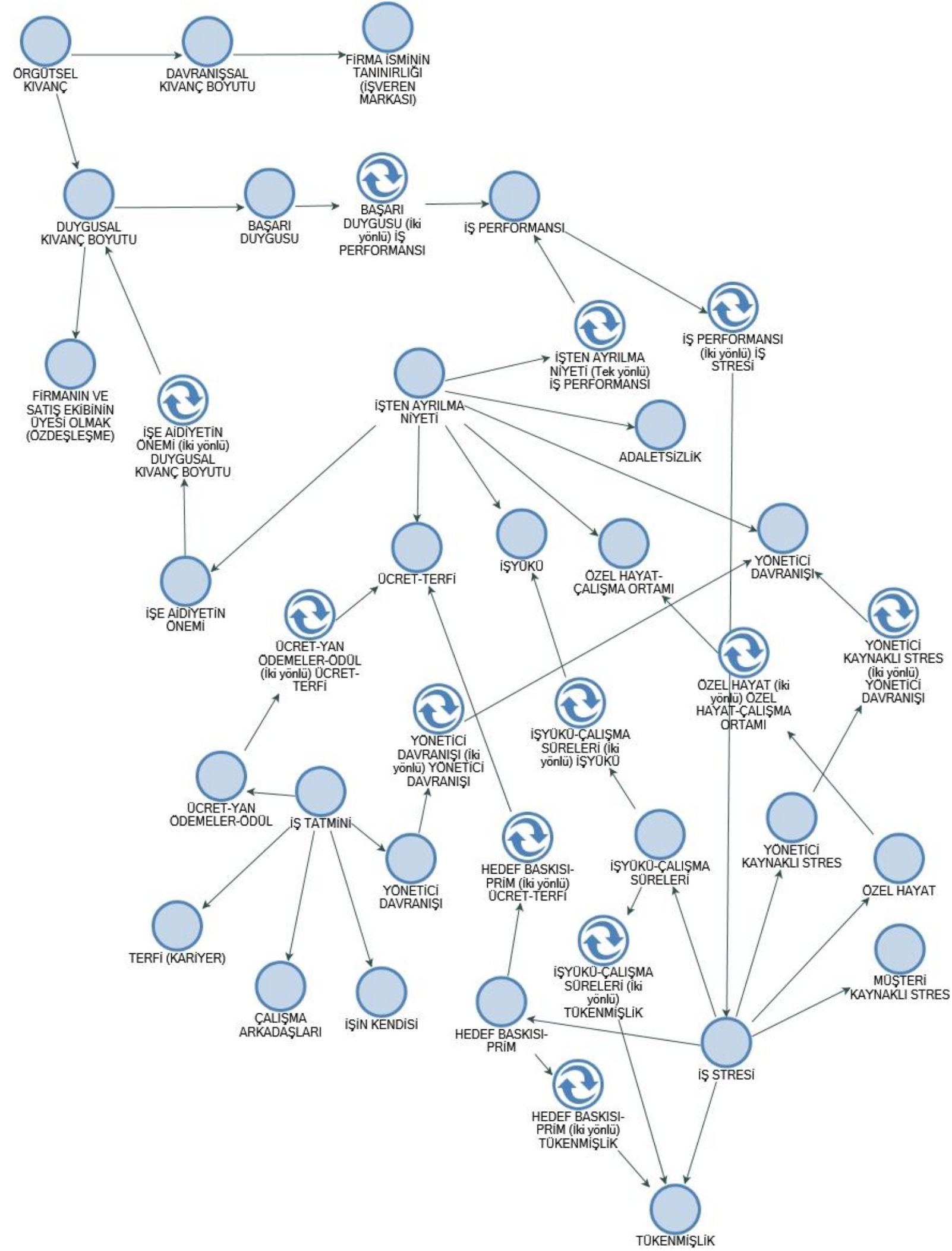

Şekil 1. Nitel Veri Analizi ile Kategori-Tema-Alt Tema ve Aralarındaki İlinti Haritası 


\section{Tartışma ve Sonuç}

$\mathrm{Bu}$ çalışmanın temel amacı, iş stresi, iş tatmini, örgütsel kıvanç, iş performansı ile işten ayrılma niyetinin telekomünikasyon şirketinde çalışan satış temsilcilerinde araştırılması ve işten ayrılma niyetinin öncüllerinin belirlenmesidir. Bu kapsamda, araştırma verileri beş temel temaya ayrılmıştır. İş stresi temasının, hedef baskısı-prim, işyükü-çalışma süreleri, yönetici kaynaklı stres, müşteri kaynaklı stres ve özel hayat, tükenmişlik alt temalarından oluştuğu belirlenmiştir. Hedef baskısı-prim ile işyükü-çalışma süreleri, iş stresi teması içinde ilk iki sırada yer alan alt temalardır. Ayrıca katılımcıların ifadelerinden, iş yükünün iş stresini arttırdığına yönelik bulgular tespit edilmiştir. Tükenmişlik alt temasının da hedef baskısı ve iş yükü ile ilintili olarak ortaya çıktığı belirlenmiştir. İş stresinin diğer temalarla ilgisine bakıldığında; iş stresini oluşturan işyükü-çalışma süreleri, hedef baskısı-prim, yönetici kaynaklı stres, özel hayat alt temalarının, işten ayrılma niyetiyle de ilintili çıktığı tespit edilmiştir. İş stresi temasındaki yönetici kaynaklı stres ve hedef baskısı-prim alt teması, işten ayrılma niyeti temasındaki yönetici davranışı ile ücret-terfi alt temaları üzerinden iş tatmini temasının, ücret-yan ödemeler-ödül ve yönetici davranışı alt temalarıyla ilintilidir. Literatürdeki diğer çalışmalar incelendiğinde; Dülgeroğlu ve Başol'un (2017) satış temsilcilerinin çalışma yaşamı kalitesi algılarının ve iş stresinin; iş performansına, iş tatminine ve işten ayrılma niyetine olan etkisini araştırdığı çalışmada, iş stresinin işten ayrılma niyetini arttırdığını, iş tatminini azalttığını, ancak iş performansı ile ilintili olmadığını vurgulamıştır. Masihabadi vd. (2015) çalışmasında, iş stresinin hem iş performansını, hem de iş tatminini negatif etkilediğini tespit etmişlerdir. Mevcut çalışmada ise, iş stresinin iş performansı temasıyla ilintisi belirlenerek bu sonuç desteklenmiştir (bkz. Tablo 7). Sin ve Yau (1995) tarafından satış temsilcileri üzerine yapılan çalışmada, bu araştırmayı destekler nitelikte, iş stresi ile işten ayrılma niyeti arasında pozitif bir ilişki bulunduğu belirtilmektedir. Buna ek olarak, satış temsilciliği dışında başka meslek grupları için de bu ilişkinin yinelendiği görülmektedir (Onay ve Kılc1, 2011; Jung ve Yoon, 2014; Yenihan, 2014; Lee vd., 2016; Dülgeroğlu ve Başol, 2017). Bu sonuçtan hareketle, mevcut ilinti bağlamında araştırma bulguları ile literatürdeki bulguların benzerlik gösterdiğini belirtmek yerinde olacaktır. Ayrıca, iş stresini azaltmak için, yöneticilerin çalışanlardan beklentilerinin açık olması, karşılıklı güvene dayalı, yardımsever, arkadaşça ve samimi bir iş ortamı yaratılması sağlanabilir (Schwepker ve Ingram, 2016). Firth vd.'nin (2004) Avusturalya'da perakende sektöründe 173 satış personeli üzerine yürüttüğü çalışmada iş stresini etkileyen unsurların işe bağlılığa ve işten ayrılma niyetine olan etkisi incelenmiştir. Çalışmaya göre, iyi bir ast-üst ilişkisinin iş stresi üzerinde yarattığı etki önemlidir. Bu sonuçlar araştırmanın sonuçları ile aynı doğrultudadır.

Çalışmanın ikinci ana teması iş tatminidir. Ücret-yan ödemeler-ödül, yönetici davranışı, çalışma arkadaşları, terfi (kariyer), işin kendisi bu temanın alt temaları olarak ortaya çıkmaktadır. İş tatmininin diğer temalar ile ilintisi incelendiğinde; ücret-yan ödemeler-ödül ve yönetici davranışı alt teması işten ayrılma niyetiyle ve ayrıca yine aynı alt temalar iş stresi ile de ilintilidir. Bu çalışma sonucunda, iş tatmininin alt temaları diğer temalarla daha az ilintili çıkmıştır. Çalışma arkadaşları alt temasının ifadelerinden, tüm katılımcıların iş arkadaşlarından memnun oldukları ve onları aileleri olarak benimsedikleri belirlenmiştir. $\mathrm{Bu}$ sonuç, aidiyet duygusunu güçlendiricidir. Yönetici davranışı, çalışmadaki örneklemde, iş tatminini önemli ölçüde ilgilendiren bir unsur olarak bulunmuştur. Yapraklı ve Yılmaz (2007), iş stresi algısının iş tatmini üzerindeki etkisinin ilaç mümessilleri üzerinde yaptığı çalışmada; çalışanların, yöneticilerinden memnun oldukları ancak ücret ve çalışma şartlarından tatmin olmadıkları sonucuna ulaşmışlardır. Bu araştırmada ise, iş tatmini temasında yönetici davranışı ve ücret iki temel unsur olarak ortaya çıkmaktadır. Yöneticinin çalışanlarına olumsuz yönde davranışı işten ayrılma niyetinin gelişmesine sebep olmaktadır. Araştırmada yönetici davranışı kavramının ön plana çıkması, çalışanların iş yaşamında oluşan duygusal deneyimlerinin onların iş tatminini ve performansını olumlu etkilediği temelinde oluşan Duygusal Olaylar kuramına (Affective Events Theory) (Weiss ve Cropanzano, 1996) dayandırılabilir. $\mathrm{Bu}$ kuram çerçevesinde bulgular incelendiğinde, adaletli çalışma ortamının, pozitif liderlik davranışının, insancıl bir muamele ile olumlu çalışma ortamı ve koşullarının yaratılmasının çalışanların motivasyonunu olumlu etkileyebildiği, bunun yanında günlük rutin işleri sırasında duyulan duygusal gururun çalışan memnuniyetine veya memnuniyetsizliğine sebebiyet verdiği yorumlanabilmektedir (Gouthier ve Rhein, 2011).

Örgütsel kıvanç teması, duygusal ve davranışsal kıvanç olarak iki alt temada toplanmıştır. Firmanın ve satış ekibinin üyesi olmak (özdeşleşme) ile başarı duygusu alt temaları belirgin bir şekilde ortaya çıkmaktadır. Özelikle, duygusal kıvanç alt temasında yer alan başarı duygusu kodu diğer temalardan olan iş performansı için olumlu motivasyon kaynağı olarak ifadelerde belirtilmiştir. İşten ayrılma niyetinin işe aidiyet alt kodu ise yine örgütsel kıvancın duygusal boyutu ile ilintilidir. Firma isminin tanınırlığı (işveren markası) kodu ise davranışsal kıvancın alt temasında yer almaktadır. Tüm bu temalar değerlendirildiğinde, satış temsilcilerinin başarı duygusunun örgütsel kıvanç ile pekiştirildiği ve örgütün başarısına yansıdığı belirlenmektedir. Çünkü satış hedefleri yükselirken çalışanların motivasyon gücünü destekleyici öncüller örgütsel kıvanç-örgütsel başarı unsuru olabilmektedir. Örgütsel kıvanç olgusu literatürde incelendiğinde, başarının kutlanması çalışanların örgütsel kıvancın deneyimlemesi için önemli bir etken olduğu belirtilmektedir. Örgütsel kıvancın kaynağını, işletmenin piyasadaki konumu, işletmenin büyüklüğü, imajı ve markaları gibi ekonomik özellikleri (Scott ve Lane, 2000) ile işletmenin kültürü, değerleri, gelenekleri ve iş ahlakı oluşturmaktadır (Anfuso, 1995). Ayrıca, başarılı reklam kampanyaları ve ünlü müşterilerin kazanılması örgütsel kıvancın oluşmasını teşvik etmektedir (Celsi ve Gilly, 2010). Kashif vd. (2017) çalışmasında, örgütsel kıvancın çalışan-örgüt ilişkisinde aracı rolü olduğunu belirtmiştir. Bu çalışmanın sonuçları, çalışanların adaletli bir çalışma ortamıyla ve örgütsel kıvanç duygusu sağlama ile çalışanların tükenmişlik duygularını azaltıcını rolünü göstermiştir. Bu şekilde adaletli davranarak, çalışanların kıvanç duymalarını 
sağlayıcı politikalar oluşturarak, otoriteyi delege ederek, çalışanların örgüte katılımlarını arttırarak bağlılıklarının güçlendirilebileceği ifade edilmiştir (Kashif vd., 2017). Tüm bu temalar değerlendirildiğinde, satış temsilcilerinin başarı duygusunun örgütsel kıvanç ile pekiştirildiği ve örgütün başarısına yansıdığı belirlenmektedir. Çünkü satış hedefleri yükselirken çalışanların motivasyon gücünü destekleyici öncüller örgütsel kıvanç- örgütsel başarı faktörü olabilmektedir.

Çalışmada, işten ayrılma niyeti temasının altında yönetici davranışı, ücret-terfi, işe aidiyetin önemi, adaletsizlik, işyükü, çalışma ortamı ve özel hayat olarak yer alan altı alt tema çıkmaktadır. Yönetici davranışının ilk öncül olarak yer alması, yönetici kaynaklı sorunlu iletişim ortamı; huzursuz, yıpratıcı çalışma koşulları olarak değerlendirilebilir. İşten ayrılma niyeti temasının diğer temalarla ilintisi incelendiğinde; satış temsilcisinin hissettiği iş stresi ile işten ayrılma niyetinin ortak alt temaları, yönetici davranışı, işyükü-çalışma süreleri ve özel hayattır. İş stresindeki hedef baskısı-prim alt teması, işten ayrılma niyetindeki ücret-terfi ile karşılıklı ilintili durumundadır. Bunun sebebi ise, satış sektöründe ücretlerin hedef ve prim temelli olmasından kaynaklanmasıdır. Ayrıca, iş stresinin tükenmişlik alt teması, hedef baskısıprim ve işyükü-çalışma süreleri ile ilintili olduğundan, bu alt tema da işten ayrılma niyetiyle ilintilidir. İş tatmini-işten ayrılma niyetinin ise birbiriyle ilintili olduğu, yönetici davranışı ile ücret-yan ödemeler-ödül ortak temalarından oluştuğu belirlenmektedir. İşten ayrılma niyetinin işe aidiyetin önemi alt teması, örgütsel kıvanç temasının duygusal kıvanç boyutu ile ilintidir. Kendini işine ait hissetmeyen ve performans düşüklüğü yaşayabilen çalışan, işyerine karşı bağlılık kuramadığ 1 için işten ayrılmaya karar verebilmektedir. İşten ayrılma niyeti; örgütsel kıvanç duygusunun pekiştirilmesi, iş stresinin azaltılması, iş tatmini temasındaki ücret-prim-ödül boyutunun güçlendirilmesi ile engellenebilir. Çalışmanın bulgularında, kurumsal ve işveren markası olarak, bilinen işletmede çalışan satış temsilcilerinin, çalıştı̆̆ firmaya dair hissettiği kıvanç duygusunun işten ayrılma niyetini etkileyebileceği belirlenmiştir.

Son olarak iş performansı teması bulguları incelendiğinde, bu temaya ait alt temaların oluşmadığı görülmektedir. İş performansıyla ilintili temalar ise iş stresi, örgütsel kıvanç ve işten ayrılma niyetidir. Katılımcıların ifadelerine göre, iş performansını arttıran en önemli özellik, örgüte yönelik hissedilen kıvanç ile başarı duygusudur. İş stresinin yarattığı moral bozukluğu ve işten ayrılma niyeti, yine ifadeler doğrultusunda çalışan performansını azaltıcı niteliktedir. Satış temsilcilerinin yoğun iş stresi ve performansının azalışı literatürde benzer şekilde desteklenmektedir. Hizmet sektöründe çalışanların, artan müşteri istekleri karşısında yaşadıkları stres ve büyüyen kaygılar nedeniyle işlerinden memnun olmadıkları, bu durumun performanslarını da olumsuz yönde etkilediği sonucuna varılmıştır (Choi vd., 2014; Kashif vd., 2017). Çalışanların motivasyon, bilgi ve bağlılığı herhangi bir hizmet işletmesi için başarıda ana unsurdur. Bu bakımdan yöneticiler, olumlu bir iş yeri kültürü yaratmalıdırlar (Chiang ve Hsieh, 2012). Özellikle iş performansı ve örgütsel kıvanç temalarının, örgütsel performans ve başarıya etkisi ayrıca incelenmeli ve araştırılmalıdır.

Çalışma genel olarak değerlendirildiğinde, iş stresi, örgütsel kıvanç, iş tatmini ve işten ayrılma niyeti arasındaki etkileşimin bir sektör özelinde incelenerek (telekomünikasyon sektörü) bu bağlamda çalışan satış temsilcileri üzerine yapılmış olması, hem literatüre hem de sektöre katkı sağlayabileceği düşünülmektedir. Böylelikle araştırma sonuçlarının örgütsel davranış, insan kaynakları, stratejik yönetim gibi belirli araştırma alanlarına özellikle katkı sağlayacağına inanılmaktadır. Ancak, her ne kadar araştırma akademik ve pratik alanlar için önemli bulgular sunsa da, çalışmanın nitel araştırma olup beş satış temsilcisi ile derinlemesine görüşme şeklinde yapılması çalışma sonuçlarının genellenebilirliğini engellemektedir. Dolayısıyla, gelecek çalışmalarda, çeşitli sektörlerde görev alan satış temsilcileri daha büyük sayılarda dahil edilerek araştırma zenginleştirilebilir. Bunun yanı sıra, bu çalışmadan elde edilen temalar çerçevesinde alt temalar ve kodlar kullanılarak nicel yöntemler de (anket gibi) sonraki araştırmalarda uygulanabilir. 
Ercan, A., Kazançoğlu, İ., Küçükaltan, B. / Journal of Yasar University, 2019, 14 (Special Issue), 101-114

\section{KAYNAKÇA}

Anfuso, Dawn. 1995. “3M's Staffing Strategy Promotes Productivity and Prid”. Personnel Journal, 74(2), 28-33.

Armağan, Ece, \& Kubak, Sibel. 2013. "Satış Elemanlarının Stres Düzeylerinin Performanslarına Etkisi Üzerine Bir Uygulama”. Organizasyon ve Yönetim Bilimleri Dergisi, 5(2), 34-50.

Armstrong, Micheal, \& Taylor, Stephen. 2014. Armstrong's Handbook of Human Resource Management Practice. Kogan Page Publishers.

Arnold, Todd, Landry Timothy D., Scheer, Lisa K., \& Stan, Scheer \&Simona. 2009. "The Role of Equity and Work Environment in the Formation of Salesperson Distributive Fairness Judgments". Journal of Personal Selling \& Sales Management, 29(1), 61-80.

Bande, Belen, Fernández-Ferrín, Pilar, Varela, José A., \& Jaramillo, Fernando .2015. "Emotions and Salesperson Propensity to Leave: The Effects of Emotional Intelligence and Resilience". Industrial Marketing Management, $44,142-153$.

Banerjee, Sudatta, \& Mehta, Payal. 2016. "Determining The Antecedents of Job Stress and Their Impact on Job Performance: A Study Among Faculty Members”. IUP Journal of Organizational Behavior, 15(2), 7-24.

Basch, John \& Fisher, Cynthia. 2000. "Affective Events-Emotions Matrix: A Classification of Work Events and Associated Emotions”, in Ashkanasy, N.M., Härtel, C.E.J. and Zerbe, W.J. (Eds), Emotions in the Workplace, Westport, London, 36-48.

Bhuiana, Shahid N., Menguc, Bulent \& Borsboom, Rene. 2005. "Stressors and Job Outcomes in Sales: A Triphasic Model Versus a Linear-quadratic-interactive Model". Journal of Business Research, 58, 141- 150.

Celsi, Mary Wolfinbarger \& Gilly, Mary C. 2010. "Employees as Internal Audience: How Advertising Affects Employees' Customer Focus". Journal of the Academy of Marketing Science, 38(4), 520-529.

Chiang, Chun-Fan, \& Hsieh, Tsung-Sheng. 2012. "The Impacts of Perceived Organizational Support and Psychological Empowerment on Job Performance: The Mediating Effects of Organizational Citizenship Behavior". International journal of hospitality management, 31(1), 180-190.

Choi, Jung Eun, Lee, Kyoung Mee, \& Hwang, Sun Ji. 2014. "The Effects of Service Education and Empowerment for Sales Person of Fashion Companies on Customer Orientation, Job Performance and Job Satisfaction". The Research Journal of the Costume Culture, 22(1), 28-41.

Çekmecelioğlu, Hülya Gündüz, \& Dinçel, Güler. 2014. “Çalışanların Kurumsal İtibara İlişkin Algıları ve Bu Algıların Örgütsel Kıvanç, Örgütsel Bağlılık ve İş Tatmini Üzerindeki Etkileri: Doğu Marmara Bölgesi Plastik Ambalaj Sanayi Üzerinde Bir Araştırma”. Business \& Economics Research Journal, 5(2), 79-94.

Durrah, Omar, Chaudhary, Monica, \& Gharib, Moaz. 2019. "Organizational Cynicism and Its Impact on Organizational Pride in Industrial Organizations". International journal of environmental research and public health, 16(7), 1203.

Dülgeroğlu, İsmail, \& Başol, Oğuz. 2017. "İş Stresi ve Çalışma Yaşamı Kalitesi Algısının Yansımaları: Satış Temsilcileri Üzerine Bir Araştırma". Business and Economics Research Journal, 8(2), 293-304.

Ercan, Aslı, \& Kazançoğlu, İpek. 2019. “Algılanan Örgütsel Sinizmin Mesleki Tükenmişlik Olgusuyla İlişkisi: Satış Personeli Üzerine Bir Araştırma”. Organizasyon ve Yönetim Bilimleri Dergisi, 11(2), 1-19.

Erdem, Haluk \& Erkan, Gökdeniz, Kalkın. 2015. "Kamu Çalışanlarının Yaşadıkları İş-Aile ve Aile-İş Çatışmasının İş Tatminsizliğine Olan Etkisinde Örgütsel Sinizmin Aracılık Rolü”, International Journal of Social Science, (37): 351-369.

Eren, Erol. 2010. Örgütsel Davranışv ve Yönetim Psikolojisi, 12. Baskı, İstanbul: Beta Basım Yayın Dağıtım A.Ş.

Fairfield, Kent D. \& Wagner, Robert F. 2004, "Whose Side Are You on? Interdependence and Its Consequences in Management of Healthcare Delivery”, Journal of Healthcare Management, Vol. 49 No. 1, 17-29.

Faiz, Emel. 2019. “Aşırı İş Yükü ve Tükenmişlik Sendromunun İşten Ayrılma Niyeti Üzerindeki Etkisi: Satış Personelleri Üzerinde Bir Araştırma”. Çalışma İlişkileri Dergisi, 10(1), 26-38.

Firth, Lucy, Mellor, David, Moore, Kathleen A \& Loquet, Claude. 2004. "How Can Managers Reduce Employee Intention to Quit?". Journal of managerial psychology, 19(2), 170-187.

Fong, Yoong Lee \& Mahfar, Mastura. 2013. "Relationship Between Occupational Stress and Turnover Intention Among Employees in A Furniture Manufacturing Company in Selangor”. Sains Humanika, 64(1).

Gouthier, Matthias H.J. \& Rhein, Miriam. 2011. "Organizational Pride and Its Positive Effects on Employee Behavior", Journal of Service Management, 22 (5), 633-649.

Gunter, Barrie, \& Furnham, Adrian. 1996. "Biographical and Climate Predictors of Job Satisfaction and Pride in Organization". The Journal of psychology, 130(2), 193-208.

Güler, Ahmet., Halıcıoğlu, Mustafa Bülent \& Taşğın, Serkan. 2015. Sosyal Bilimlerde Nitel Araştırma: Teorik Çerçeve, Pratik Öneriler, 7 Farklı Nitel Araştırma Yaklaşımı, Kalite ve Etik Hususlar, 2.Baskı, Ankara, Seçkin Yayıncılık.

Helm, Sabrina. 2011. “Employees' Awareness of Their İmpact on Corporate Reputation”. Journal of Business Research, 64(7), 657-663.

İşcan, Ömer Faruk \& Sayın, Ufuk. 2010. “Örgütsel Adalet, İş Tatmini ve Örgütsel Güven Arasındaki İlişki”. Atatürk Üniversitesi İktisadi ve İdari Bilimler Dergisi, 24(4), 195-216.

Janssen, Onne \& Van Yperen, Nico W. 2004. “Employees' Goal Orientations, The Quality of Leader-Member Exchange, and The Outcomes of Job Performance and Job Satisfaction”. Academy of management journal, 47(3), 368-384. 
Ercan, A., Kazançoğlu, İ., Küçükaltan, B. / Journal of Yasar University, 2019, 14 (Special Issue), 101-114

Jaramillo, Fernando, Nixon, Robert, \& Sams, Doreen. 2005. "The Effect of Law Enforcement Stress on Organizational Commitment”. Policing: An International Journal of Police Strategies \& Management, 28(2), 321-336.

Jung, Hyo Sun \& Yoon, Hye Hyun. 2014. “Antecedents and Consequences of Employees' Job Stress in A Foodservice Industry: Focused on Emotional Labor and Turnover Intent”. International Journal of Hospitality Management, $38,84-88$

Kashif, Muhammad, Zarkada, Anna \& Thurasamy, Ramayah. 2017. "Customer Aggression and Organizational Turnover Among Service Employees: The Moderating Role of Distributive Justice and Organizational Pride". Personnel Review, 46(8), 1672-1688.

Küçükaltan, Berk. 2018. "Örgütsel Başar1-Performans Açısından Yönetim”, Akdemir, A. (Ed.) Örgütlerin Yönetimi: Kavramsal-Kuramsal,Tematik ve Kurumsal Açılardan Yönetim, 356-371, İstanbul: Beta Yayınları.

Kraemer, Tobias, \& HJ Gouthier, Matthias. 2014. "How Organizational Pride and Emotional Exhaustion Explain Turnover Intentions in Call Centers: A Multi-Group Analysis With Gender and Organizational Tenure". Journal of Service Management, 25(1), 125-148.

Lee, Pyoung Jik, Lee, Byung Kwon, Jeon, Jin Yong, Zhang, Mei \& Kang, Jian. 2016. "Impact of Noise on Self-Rated Job Satisfaction and Health in Open-Plan Offices: A Structural Equation Modelling Approach". Ergonomics, 59(2), 222-234.

Masihabadi, Abolghasem, Rajaei, Alireza, Shams Koloukhi, Amir, \& Parsian, Hossein. 2015. "Effects of Stress on Auditors' Organizational Commitment, Job Satisfaction, and Job Performance". International Journal of Organizational Leadership, 4, 303-314.

Olusegun, Adetayo Joshua, Oluwasayo, Ajani John, \& Olawoyim, Olabisi. 2014. "An Overview of The Effects of Job Stress on Employees Performance in Nigeria Tertiary Hospitals. Ekonomika”, Journal for Economic Theory and Practice and Social Issues, 62(1350-2019-2737), 139-153.

Onay, Meltem, \& Kılcı, Sevde. 2011. "İş Stresi ve Tükenmişlik Duygusunun İşten Ayrılma Niyeti Üzerine Etkileri: Garsonlar ve Aşçıbaş1lar”. Organizasyon ve Yönetim Bilimleri Dergisi, 3(2), 363-372.

Parker, Donald F., \& DeCotiis, Thomas A. 1983. "Organizational Determinants of Job Stress". Organizational Behavior And Human Performance 32, 160-177.

Pettijohn, Charles E., Pettijohn, Linda S., \& Taylor, Albert J. 2007. "Does Salesperson Perception of The Importance of Sales Skills Improve Sales Performance, Customer Orientation, Job Satisfaction, and Organizational Commitment, and Reduce Turnover?”. Journal of Personal Selling \& Sales Management, 27(1), 75-88.

Polat, Mustafa, \& Meydan, Cem Harun. 2010. “Örgütsel Özdeşleşmenin Sinizm ve İşten Ayrılma Niyeti ile İlişkisi Üzerine Bir Araştırma”. Savunma Bilimleri Dergisi, 9(1), 145-172.

Sager, Jeffrey K. 1994. “A Structural Model Depicting Salespeople's Job Stress”. Journal of the Academy of Marketing Science, 22(1), 74-84.

Schwepker Jr, Charles H., \& Ingram, Thomas N. 2016. "Ethical Leadership in The Salesforce: Effects on Salesperson Customer Orientation, Commitment to Customer Value and Job Stress". Journal of Business \& Industrial Marketing, 31(7), 914-927.

Scott, Susanne G., \& Lane, Vicki R. 2000. “A Stakeholder Approach to Organizational Identity”. Academy of Management review, 25(1), 43-62.

Sin, Leo Y., \& Yau, Oliver H. 1995. "The Antecedents and Consequences of Role Stress Among Chinese Salespersons: An Exploratory Study in Hong Kong”. Asia Pacific Journal of Marketing and Logistics, 7(1/2), 62-86.

Singh, Ramendra, \& Das, Gopal. 2013. "The Impact of Job Satisfaction, Adaptive Selling Behaviors and Customer Orientation on Salesperson's Performance: Exploring The Moderating Role of Selling Experience”. Journal of Business \& Industrial Marketing, 28(7), 554-564.

Tekingündüz, Sabahattin, Top, Mehmet, \& Seçkin, Mustafa. 2015. “İş Tatmini, Performans, İş Stresi ve İşten Ayrılma Niyeti Arasındaki İlişkilerin İncelenmesi: Hastane Örneği”". Verimlilik Dergisi, (4), 39-64.

Turunç, Ömer \& Çelik, Mazlum. 2010. "Algılanan Örgütsel Desteğin Çalışanların İş-Aile, Aile-İş Çatışması, Örgütsel Özdeşleşme ve İşten Ayrılma Niyetine Etkisi: Savunma Sektöründe Bir Araştırma”. Atatürk Üniversitesi Sosyal Bilimler Enstitüsü Dergisi, 14(1), 209-232.

Üngören, Engin., Doğan, Hulusi, Özmen, Mehmet \& Tekin, Ömer Akgün. 2010. “Otel Çalışanlarının Tükenmişlik ve İş Tatmin Düzeyleri İlişkisi”. Journal of Yaşar University, 17(5), 2922-2237.

Verbeke, Willem, Belschak, Frank, \& Bagozzi, Richard P. 2004. "The Adaptive Consequences of Pride in Personal Selling". Journal of the Academy of Marketing Science, 32(4), 386-402.

Weiss, Howard M., \& Cropanzano, Russell. 1996. "Affective Events Theory: A Theoretical Discussion of The Structure, Causes And Consequences of Affective Experiences at Work”. Research in Organizational Behavior, 18, 1-74.

Yan, Xiaofei, Su, Jingkuan, Wen, Zhihong, \& Luo, Zhengxue. 2019. "The Role of Work Engagement on The Relationship Between Personality and Job Satisfaction in Chinese Nurses". Current Psychology, 38(3), 873-878.

Yapraklı, Şükrü, \& Yılmaz, Mustafa Kemal. 2007. "Satış Gücü Motivasyonu-İş Tatmini Ölçeklerinin Test Edilmesi ve Motivasyonun İş Tatmini Üzerindeki Etkisinin Belirlenmesi: İlaç Sektöründe bir Uygulama”. ISGUC The Journal of Industrial Relations and Human Resources, 9(3), 62-98. 
Ercan, A., Kazançoğlu, İ., Küçükaltan, B. / Journal of Yasar University, 2019, 14 (Special Issue), 101-114

Yenihan, Bora. 2014. “Örgütsel Bağlılık ve İş Tatmini Arasındaki İlişki”. Karabük Üniversitesi Sosyal Bilimler Enstitüsü Dergisi, 4(2), 170-178.

Y1lmaz, Cengiz. 2002. "Salesperson Performance and Job Attudes Revised : An Extended Model and Effects of Potential Moderators". European Jounal of Marketing, 36(11/12), 1389-1414. 